\title{
PERANAN ORANG KRISTEN DALAM \\ PUSARAN POLITIK DI INDONESIA \\ (Suatu Tinjauan Historis -Teologis)
}

\author{
Samuel Benyamin Hakh \\ Sekolah Tinggi Filsafat Teologi Jakarta \\ Alamat e-mail: samuelbenyamin@ymail.com
}

\begin{abstract}
.
This paper is prepared to explain that the struggle for Indonesian independence was carried out for centuries by all people in Indonesia, including Christians, with sweat and tears, even with bloodshed. Therefore, Indonesian independence is not a gift or effort from a particular group, but it is a gift from God which is expressed through the struggle of all groups and tribes throughout Indonesia from Sabang to Merauke and from Sangir to Rote. So, as a nation which is dignified, and who upholds justice and truth, we must be honest with the history of our own nation. With that, the independence of Indonesia as a gift from God, we should be accepted with thanksgiving while we are together to build a just, prosperous, peaceful of Indonesia in the future.
\end{abstract}

[Tulisan ini disusun untuk menjelaskan bahwa perjuangan untuk mencapai kemerdekaan Indonesia telah dilakukan berabad-abad oleh seluruh rakyat di Nusantara, termasuk orang Kristen, dengan keringat dan air mata, bahkan dengan pertumpahan darah. Oleh sebab itu, kemerdekaan Indonesia bukanlah hadiah atau usaha dari suatu golongan tertentu, melainkan merupakan anugerah Tuhan yang dinyatakan melalui perjuangan semua golongan dan sukusuku di seluruh Indonesia dari Sabang hingga Merauke dan dari Sangir hingga ke Rote. Maka sebagai satu bangsa yang bermartabat, dan yang menjunjung tinggi keadilan dan kebenaran, kita harus jujur terhadap perjalanan sejarah bangsa kita sendiri. Dengan begitu kemerdekaan Indonesia sebagai anugerah Tuhan, patut kita diterima dengan ucapan syukur sambil, bersama sama membangun Indonesia yang adil, sejahtera, damai di masa depan].

\section{Pengantar}

Peranan orang Kristen dalam pusaran politik di Indonesia telah berlangsung sejak zaman penjajahan Belanda hingga sekarang. Pada awal keterlibatan orang Kristen dalam bidang politik masih dalam bentuk organisasi kedaerahan untuk mendukung kehidupan sosial, moral dan kerohanian masyarakat di daerah-daerah tertentu, antara lain di Ambon, Minahasa, Timor, Jawa, Sulawesi dan Sumatera. Oganisasi-organisasi ini secara langsung maupun tidak langsung mempersiapkan rakyat Indonesia menuju kemerdekaan Indonesia. Semangat nasionalisme yang mulai bertumbuh di kalangan masyarakat mendorong adanya upaya-upaya penyatuan organisasi-organisasi itu sehingga melahirkan gerakan-gerakan yang bersifat Nasionalis. Salah satu contoh gerakan itu adalah Sumpah Pemuda yang dideklarasikan pada tanggal 28 Oktober 1928. Sesudah sumpah pemuda itu maka mulai terbentuk kelompokkelompok pemuda di berbagai daerah di Indonesia, yang berjuang bahu membahu terus menggelorakan nasionalisme tanpa membedakan agama, suku dan ras.

Gerakan nasionalisme itu ternyata bukan tanpa tantangan. Tantangan-tantangan itu terus datang baik pada masa penjajahan Belanda maupun penjajahan Jepang. Banyak aktivis yang berusaha mengajak masyarakat untuk terus meningkatkan semangat nasionalisme dalam diri maasyarakat Indonesia, ditangkap dan dipenjarakan, kemudian organisasi politiknya dibubarkan. Bahkan pada masa penjajahan Jepang, diperintahkan agar semua organisasi politik 
dibubarkan, termasuk lembaga-lembaga pendidikan. Tetapi hambatan-hambatan itu tidak menyurutkan semangat juang dari orang Kristen dan golongan agama lain di Indonesia.

Orang Kristen bersama dengan saudara-saudaranya yang sebangsa dan setanah air terus melakukan persiapan-persiapan menuju kemerdekaan Indonesia. Dibentuklah Panitia Persiapan Kemerdekaan Indonesia (PPKI). Badan inilah yang mempersiapkan Undang-undang Dasar Negara. Ketika Jepang menyerah pada Sekutu, maka baik para pemimpin maupun pemuda Indonesia waktu memproklamasikan kemerdekaan Indonesia.

Kekuasaan tidak lagi berada di tangan penjajah Balanda dan Jepang, melainkan sudah berada di tangan rakyat Indionesia. Perjalanan demokrasi sesudah Indonesia merdeka, ternyata tidak mulus. Model demokrasi pertama yang diberlakukan di Indonesia adalah demokrasi parlementer. Dalam model demokrasi ini orang Kristen mendirikan partai Kristen yang diberi nama PARKINDO. Namun dalam demokrasi ini terjadi persaingan antar idiologi partai maka Presiden Soekarno membubarkan parlemen dan mendeklarasikan demokrasi terpimpin. Namun ternyata model demokrasi ini mengarah kepada pemusatan semua kekuasaan berada di dalam satu tangan yaitu di tangan Presiden. Walau demikian, ABRI juga ingin berperan dalam bidang politik sehingga terjadi pertarungan kekuasaan antara Presiden dan ABRI.

Pada tahun 1966, ABRI mengambil-alih kekuasaan dari Presiden Soekarno dan memberlakukan demokrasi Pancasila. Namun untuk mengontrol partai-partai politik di Indonesia maka dilakukan peleburan partai-partai menjadi tiga partai yaitu Golkar, PPP dan PDI. Alhasil, PARKINDO dileburkan ke dalam PDI. Dari ketiga partai ini, partai Golkar sebagai partai penguasa yang memiliki pengaruh yang sangat besar di samping militer. Oleh karena tekanan idiologis yang sangat kuat maka rakyat menjadi tidak puas terhadap penguasa. Walau demikian, rakyat tidak bisa berbuat banyak karena memang tidak berdaya. Ketidak puasan ini memuncak dengan bersatunya para intelektual dan mahasiswa yang melakukan protes dan demonstrasi sehingga menurunkan Presiden dari tampuk kekuasaannya.

Dengan turunnya Presiden Soeharto dari kursi Presiden maka Indonesia memasuki suatu babak baru dalam sejarahnya, yaitu memasuki era reformasi. Demokrasi yang diberlakukan pada era reformasi ini adalah juga demokrasi Pancasila dengan model yang baru. Pada satu pihak nama demokrasi ini tetap sama dengan masa Orde Baru. Tetapi pada pihak lain, telah membuka kemungkinan multi partai mirip seperti demokrasi parlementer pada era Soekarno. Rakyat diberikan kesempatan untuk memilih pemimpinnya secara langsung, bebas dan rahasia. Rakyat juga dapat memberikan kritik kepada pemerintah sebagai kontrol dalam menjalankan pemerintahan.

\section{Peranan Orang Kristen dalam Pusaran Politik pada Masa Penjajahan Belanda dan Jepang}

A. Masa Penjajahan Belanda .

Orang Kristen di Indonesia sudah berperan dalam bidang politik sejak zaman penjajahan Belanda. Setelah pergerakan Budi Utomo pada tanggal 20 Mei 1908, yang telah membangkitkan semangat Nasionalisme di kalangan para pejuang dan masyarakat Indonesia. Salah satu tujuan dari pergerakan Budi Utomo adalah berusaha untuk melaksanakan cita-cita persatuan Indonesia. ${ }^{1}$ Semangat persatuan itu memotivasi suku-suku Ambon dan Menado untuk bersatu. Maka pada 1 September 1908, para anggota tentara di bawah pimpinan J.P. Risakotta membentuk suatu perkumpulan yang terdiri dari anak-anak Ambon dan Manado dengan nama Wilhelmina.

\footnotetext{
${ }^{1}$ Poltak J.B. Sibarani, Bolehkah Gereja Berpolitik. Mencari Pola Hubungan Gereja dan Negara yang relevan di Indonesia (Jalarta: Ramos Gospel Bubl. House, 2004) h. 151
} 
Organisasi ini disahkan pada 18 Januari 1912. Tujuan organisasi ini adalah menyatukan suku-suku Ambon dan Manado untuk menghilangkan permusuhan dan memperkuat ikatan persatuan. ${ }^{2}$ Upaya meningkatkan semangat persatuan dan nasionalisme juga dilakukan melalui pendirian organisasi politik yang didasarkan pada agama Kristen yang diberi nama: Christelijke Ambonsche Volksbond (CAV) yang didirikan pada tahun 1917 di Ambon dengan Ketua: W. Pattiasina, seorang pendeta pribumi (Inlandsch Leeraar). Tujuan organisari ini adalah "meningkatkan persatuan orang Ambon, meningkatkan kesejahteraan sosial ekonomi anggotanya dan mendukung politik Christelijke Ethische Partij (CEP), yang didirikan oleh orang Belanda di Indonesia. Banyak orang Indonesia pribumi yang masuk sebagai anggota partai ini sehingga di Sangir didirikanlah tiga cabang dari partai ini. Namun dikemudian hari orang Belanda kurang senang apabila orang-orang Kristen pribuni menjadi anggota partai ini, sehingga pada tahun 1920 orang Kristen mendirikan organisasi sendiri yang diberi nama: "Perkumpulan Kaum Christen" (PKC) dipimpin oleh Dr. Ismael dari Modjowarno. Beberapa organisasi Kristen lainnya, yang bersifat politis adalah Perserikatan Kaum Masehi Indonesia (PKMI), Persatuan Christen Indonesia (PERCI) yang didirikan oleh S.M. Simatupang.

Dalam rangka mendukung pergerakan Nasional maka dibentuk satu organisasi politik orang Maluku di Semarang pada tanggal 9 Mei 1920, dengan nama Sarekat Ambon dipimpin oleh A.J. Patty yang bekerja sebagai wartawan. Tujuan organisasi ini adalah memajukan kepentingan orang Ambon dan daerahnya. Organisasi politik ini sangat progresif dalam memperjuangkan dibentuknya pemerintahan parlementer dan tuntutan kepada negeri Belanda untuk diadakan persamaan dalam segala hal menyangkut kewarganegaraan penuh. Karena sikap partai politik ini dipandang terlalu progresif sehingga dihambat oleh pemerintah Belanda. Akibatnya, partai (Sarekat Ambon) ini semakin lemah. ${ }^{3}$ Namun di kemudian hari anggotaanggota partai Sarekat Ambon yang ada di Batavia menghidupkan kembali semangat partai ini tetapi lebih bersifat moderat dan bekerjasama dengan organisasi politik lainnya untuk mencegah upaya memecah belah persatuan ${ }^{4}$

Semangat untuk meningkatkan persatuan si lingkup daerah maupun nasional semakin meningkat. Di kalangan orang Minahasa didirikanlah Perserikatan Minahasa pada tahun 1912 di Semarang dengan tujuan antara lain, memberikan bantuan peningkatan ekonomi, bantuan pendidikan bagi orang Minahasa. Pada tahun yang sama didirikanlah Indische Partaij, suatu organisasi politik yang bersifat nasional. ${ }^{5}$ Pada tahun 1915, didirikanlah Jong Java, suatu organisasi yang bersifat kedaerahan. Pada tahun 1919, didirikanlah Jong Minahasa (Minahassische StuderendenVreeniging) yang memiliki tujuan pengembangan rohani, moral dan ekonomi. Delapan tahun kemudian yaitu pada tahun 1927, organisasi kepemudaan ini dikembangkan meliputi seluruh pelajar asal Sulawesi dengan nama: "Vereeniging van Studerenden Jong Celebes". Organisasi ini ikut dalam Kongres Pemuda pada tanggal 28 Oktober 1928 yang melahirkan "Sumpah Pemuda"6

Di kalangan orang Timor di perantauan, dibentuk juga organisasi kedaerahan yang diberi nama Timorsch Verbond di Makasar pada tahun 1921, dengan tujuan untuk meningkatkan kerohanian dan moral serta kesejahteraan orang Timor. Kemudian di Kupang pada tahun 1924 dibentuk juga organisasi lain yang diberi nama: "Perserikatan Timor"

\footnotetext{
2 Zakaria J. Ngelow, Kekristenan dan Nasionalisme, Perjumpaan Umat Kristen Protestan dengan pergerakan Nasional Indonesia 1900-1950 (Jakarta: BPK Gunung Mulia, 1996) h. 57

3 Zakaria J. Ngelow, Kekristenan dan Nasionalisme, h. 58-60

${ }^{4}$ Zakaria J. Ngelow, Kekristenan dan Nasionalisme, h. 64

${ }^{5}$ T.B. Simatupang, "Partisipasi Kristen dalam Revolusi di Bidang Politik" dalam Partisipasi Kristen dalam Nation Building di Indonesia, disusun oleh W.B. Sidjabat (Jakarta: BPK., 1968) h. 15

${ }^{6}$ Zakaria J. Ngelow, Kekristenan dan Nasionalisme, h. 68,69; Lihat. juga Ch. de Jonge, "Gereja Masehi Injili Minahasa 1934-1942, Berdiri sendiri Di Bawah Perwalian" dalam Sularso Sopater, Apostole, Pengutusan (Jakarta: STT Jakarta, 1987) h. 124-154
} 
dipimpin oleh C. Frans, dengan tujuan untuk memperjuangkan kemandirian orang Timor di bidang ekonomi, kerohanian, kebudayaan dan politik. Tujuan-tujuan itu diusahakan melalui perwakilan dalam Volkraad (Dewan Rakyat). Salah satu organisasi lain yang didirikan oleh Ch. M. Pandy yang bersifat radikal diberi nama: "Sarekat Timor" kemudian diubah menjadi "Sarekat Rakyat". Tujuan organisasi ini adalah melakukan perlawanan yang bersifat militan terhadap pemerintah setempat. Akibatnya Pandy ditangkap dan diadili sehingga organisasi inipun lenyap. Namun Timor Verbond tetap berdiri dan terus memperjuangkan perlawanan terhadap penjajahan ${ }^{7}$.

Organisasi kepemudaan yang bersifat kedaerahan juga dibentuk di kalangan para pemuda Batak, Nias dan Minang. Pada tahun 1917, dibentuklah Jong Sumatera Bond yang memberikan perhatian pada penyatuan suku-suku bangsa yang berada di Sumatera. Kemudian pada tahun 1925, dibentuklah Jong Bataks Bond yang memberikan perhatian pada persoalan sosial dan keagamaan dan pada tahun 1930 didirikanlah Hatopan Kristen Batak, suatu organisasi keagamaan nasionalis yang bersifat lokal ${ }^{8}$. Sifat nasionalis itu terbukti dari upaya organisasi Kristen ini yang tidak membangun hubungan dengan CEP, melainkan dengan Sarekat Islam ${ }^{9}$

Semangat nasionalisme dan persatuan semakin mendorong upaya-upaya untuk menyatukan organisasi-organisasi kedaerahan di Nusantara menjadi organisasi-organisasi yang bersifat nasional. Organisasi-organisasi itu antara lain, Perserikatan Nasional Indonesia yang didirikan pada tahun 1927 dan pada tahun yang sama didirikan PPPKI yang berusaha menghimpun perkumpulan-perkumpulan kebangsaan. Lalu menyusul didirikannya Gerindo oleh Mr. Amir Sjarifudin pada tahun 1937, dan GAPI (Gabungan Politik Indonesia) pada tahun $1939^{10}$.

Perlu dicatat bahwa peranan orang Kristen dalam bidang politik, tidak hanya organisasi politik yang bersifat Kristen melainkan organisasi yang bersifat nasional. Sebagai contoh, Mr. Amir Sjarifudin. Ia lahir dari keluarga Islam, kemudian menjadi Kristen sewaktu kuliah di Fakultas Hukum di Jakarta. Sebagai orang Kristen, ia memiliki perhatian yang besar pada bidang teologi dan gereja, sekaligus menjadi pemimpin gerakan Nasional. Contoh lain adalah, upaya yang dilakukan oleh Dr. Ratulangi dan Dr. Mulia untuk menyatukan orang-orang Kristen dalam partai besar seperti PNI, suatu organisasi politik yang bersifat Nasional. Sikap politik ini menunjukan bahwa, peranan orang Kristen di bidang politik tidak hanya melalui organisasi politik yang memakai nama Kristen melainkan juga melalui organisasi politik yang bersifat Nasional.

Pada tahun 1941, diadakanlah suatu Konferensi di Karangpandan di mana hadir orangorang Kristen Indonesia (Dr.Mulia, Mr. Amir Sjarifudin, Dr. Leimena, Abednego dan Soewidji, yang menggumuli persoalan-persoalan yang akan dihadapi oleh bangsa dan gereja masa depan ${ }^{11}$. Dalam Konferensi ini dibahas sikap politik dari orang Kristen di Indonesia, yang didahului dengan ceramah yang disampaikan oleh Soewidji yang berjudul "De roeping der Kerken op politiek terrein" (Panggilan Gereja-gereja di Bidang Politik). Dalam ceramah itu Soewidji, antara lain, menyesali kurangnya upaya dari para zending untuk untuk meningkatkan kesadaran politik di kalangan orang Kristen pribumi. Ia juga meminta kepada gereja-gereja

\footnotetext{
${ }^{7}$ Zakaria J. Ngelow, Kekristenan dan Nasionalisme, h. 70,71

${ }^{8}$ T.B. Simatupang, "Partisipasi Kristen dalam Revolusi di Bidang Politik" dalam Partisipasi Kristen dalam Nation Building di Indonesia h. 15

${ }^{9}$ T.B. Simatupang, "Partisipasi Kristen dalam Revolusi di Bidang Politik" dalam Partisipasi Kristen dalam Nation Building di Indonesia, h. 17

${ }^{10}$ T.B. Simatupang, "Partisipasi Kristen dalam Revolusi di Bidang Politik" dalam Partisipasi Kristen dalam Nation Building di Indonesia, h. 16

11 T.B. Simatupang, "Partisipasi Kristen dalam Revolusi di Bidang Politik" dalam Partisipasi Kristen dalam Nation Building di Indonesia, h. 19
} 
agar memberikan pedoman bagi orang-orang Kristen Indonesia dalam kegiatan politik dan menekankan perlunya prinsip-prinsip dasar kesetaraan dan kesamaan hak dalam keseluruhan kerajaan Belanda. Dalam tanggapannya terhadap ceramah itu, Mr Sjarifudin menegaskan agar dalam menalankan visi politik, orang Kristen harus berdiri berdampingan dengan orang-orang Islam dan para nasionalis dalam merumuskan idiologi bangsa Indonesia ke depan ${ }^{12}$

\section{B. Masa Penjajahan Jepang}

Pada bulan Maret 1942, tentara Jepang menduduki seluruh Indonesia, lalu Jepang memerintahkan agar semua Perguruan Tinggi ditutup dan semua organisasi dibubarkan. Beberapa bulan kemudian Jepang mengijinkan dibuka kembali Pergurun Tinggi Kedokteran di Jakarta. Setiap pagi sebelum kuliah dimulai semua barisan harus menghormati Teino Heika dengan membungkukkan badan ke arah Tokio. Selain itu ada paksaan untuk menghormati Tjireido (tempat penyimpanan abu mayat tentara Dai Nippon di gereja Imanuel sekarang). Mereka yang tidak menuruti perintah akan dipenjarakan ${ }^{13}$. Gereja juga mengalami perlakuan yang sama. Di Ambon misalnya, ada 90 pendeta dan tua-tua jemaat dibunuh karena menolak untuk menempatkan bendera Jepang di mimbar gereja dan menyembah sujud kepada kaisar Jepang sebelum kebaktian dimulai.

Namun di bidang politik, atas anjuran dari Shimizu, seorang pejabat yang terkenal dalam tentara Jepang, melalui Rufinus L. Tobing SH, dibentuklah BPPKK (Badan Persiapan Persatuan Kaum Kristen) yang berpusat di Kramat no. 65. Jakarta. Badan ini melakukan pelayanan sosial untuk korban-korban perang. ${ }^{14}$ Badan ini dipimpin oleh Mr. Amir Sjarifudin, Mr. Rufinus L. Tobing, Pendeta Probowinoto, Drs. Kajadu, dll. Ada kekuatiran bahwa Jepang menggunakan Badan ini sebagai alat untuk menguasai gereja. Kekuatiran itu nampak dalam pidato Amir Sjarifudin pada perayaan Natal tahun $1942 .{ }^{15}$ Sesudah perayaan itu, ia ditahan oleh pemerintah Jepang.

Perlu dicatat bahwa selama masa penjajahan Jepang, orang-orang Kristen yang berperan dalam penyusunan UUD 1945 adalah, Dr. Ratulangi, Mr. Latuharhary, Mr. Yap Tjwan Bin (kemudian menjadi Kristen), Mr. A.A. Maramis. ${ }^{16}$ Setelah mendengar bahwa Jepang telah menyerah kalah pada Sekutu maka pada tanggal 16 Agustus 1945, para mahasiswa berkumpul di asrama Prapatan 10 dibawah kordinasi Piet Mamahit. Ia menegaskan bahwa "saatnya telah tiba bagi kita untuk memproklamasikan kemerdekaan bangsa dan negara kita....". Pada tanggal 17 Agustus 1945, dua regu dari para mahasiswa di antaranya, Frans Pattiasina, Sidartha dan Joel Therik mengikuti upacara proklamasi kemerdekaan ${ }^{17}$

Dengan demikian dapat dikatakan bahwa orang Kristen telah berperan dalam bidang politik baik pada zaman penjajahan Belanda maupun pada masa penjajahan Jepang. Memang, pada awalnya pergerakan politik itu dimulai dari organisasi-organisasi kedaerahan tetapi kemudian ada upaya menyatukan organisasi-organisasi itu sehingga menjadi kekuatan yang bersifat nasional untuk melawan penjajahan. Pada masa penjajahan Jepang, sekalipun gereja mengalami penghambatan, tetapi semangat nasionalisme itu terus mendorong orang-orang Kristen sehingga mereka tetap giat dalam bidang politik, terutama dalam rangka

\footnotetext{
12 Zakaria J. Ngelow, Kekristenan dan Nasionalisme, h. 168-170

${ }^{13}$ W.B. Sidjabat, "Partisipasi Pemuda Kristen dalam Nation Building di Indonesi dalam abad ke XX" dalam Partisipasi Kristen dalam Nation Building di Indonesia, h. 47.

${ }^{14}$ Zakaria J. Ngelow, Kekristenan dan Nasionalisme, h. 173

${ }^{15}$ T.B. Simatupang, "Partisipasi Kristen dalam Revolusi di Bidang Politik" dalam Partisipasi Kristen dalam Nation Building di Indonesia, h. 21

${ }^{16}$ T.B. Simatupang, "Partisipasi Kristen dalam Revolusi di Bidang Politik" dalam Partisipasi Kristen dalam Nation Building di Indonesia, h. 22

${ }^{17}$ W.B. Sidjabat, "Partisipasi Pemuda Kristen dalam Nation Building di Indonesi dalam abad ke XX" dalam Partisipasi Kristen dalam Nation Building di Indonesia, h.51
} 
mempersiapkan dasar negara menuju kemerdekaan Indonesia. Di kalangan pemuda Kristen pun tidak kalah semangatnya. Mereka bahu membahu mendukung proklamasi kemerdekaan Indonesia.

\section{Peranan orang Kristen di bidang Politik Segera Sesudah Kemerdekaan Negara Republik Indonesia}

Setelah Bung Karno dan Bung Hatta selaku Presiden dan Wakil Presiden mendeklarasikan kemerdekaan Indonesia pada tanggal 17 Agustus 1945 maka ada pertemuan khusus antara Mr. Sartono dengan Mr. A.A. Maramis di kantor BPPKK Jl. Kramat 65, untuk meminta pandangan dari para pemuka Kristen Indonesia terhadap rancangan UUD 1945 yang telah disiapkan oleh PPKI (Panitia Persiapan Kemerdekaan Indonesia). Dalam pertemuan itu dari pihak para pemuka agama Kristen menyarankan agar kalimat pada sila ketuhanan yang ditambahkan tujuh kata yakni: "kewajiban menjalankan syariat Islam bagi pemelukpemeluknya". Suatu bentuk rumusan yang mengharuskan orang Islam menjalankan syariat Islam, dan pasal yang menetapkan Presiden harus seorang Islam, dihapus dari rumusan UUD itu. Saran itu diterima oleh Muhammat Hatta dan para tokoh agama Islam sehingga kedua pasal itu diubah. Alasannya adalah: "Oleh karena hasrat kita semua ialah menyatukan bangsa Indonesia seluruhnya"18 dan tidak ada diskriminasi warga negara serta demi penegakan negara kesatuan Indonesia yang demokratis ${ }^{19}$. Pristiwa itu merupakan saat-saat yang sangat menentukan arah perjalanan bangsa Indonesia ke depan, sekaligus merupakan peranan yang sangat penting dari orang Kristen dalam pusaran politik bangsa Indonesia.

Peranan orang Kristen, selain dalam bidang politik, juga terdapat dalam bidang militer, terutama dalam upaya mempertahankan kemerdekaan Negara Kesatuan Republik Indonesia (NKRI) yang baru dideklarasikan itu sebagai anugerah Tuhan. Demi merespons anugerah Tuhan itu maka orang-orang Kristen, sebagai warga negara, bersama-sama dengan warga negara yang lainnya, mengangkat senjata melawan penjajahan. Dalam peperangan melawan penjajahan itu banyak di antara mereka yang menjadi korban.

Orang-orang Kristen yang pernah menjadi pemimpin di bidang militer antara lain, Kol. Kawilarang, Kol. Simbolon, Laksamana Muda John Lie, Letnan Djenderal Panggabean, Mayor Djenderal Panjaitan, T.B. Simatupang, dll. Bahkan ada pasukan yang sebagian atau seluruhnya adalah orang Kristen yaitu Pasukan KRIS, pasukan Pattimura, Pasukan Istemewa di Jawa Barat, Laskar Kristen di Sumatera Utara. Sementara itu di bidang pemerintahan peranan orang Kristen terlihat pada diri Mr. Amir Sjarifudin, Mr. A.A. Maramis, Dr. Leimena, Dr. Moelia, yang duduk dalam kabinet pertama. Sedangkan Dr. Ratulangi menjadi Gubernur pertama di Sulawesi Utara dan Mr. Latuharhary menjadi gubernur pertama di Maluku. ${ }^{20}$

Sesudah proklamasi kemerdekaan diproklamasikan, maka sebagai respons terhadap maklumat pemerintah pada tanggal 3 November 1945, yang memperbolehkan rakyat Indonesia untuk mendirikan partai-partai politik dengan tujuan untuk mempertahankan kemerdekaan Negara Republik Indonesia maka pada tanggal 10 November 1945, didirikanlah partai politik Kristen yang bercorak nasional. Pendirian partai politik itu memiliki tujuan yang lebih jauh yaitu untuk memelihara dan mempertahankan kemerdekaan RI dan bersama menentukan tujuan pemerintahan berdasarkan firman Tuhan, bahwa orang Kristen mesti menjadi "garam dan terang" dalam penyelenggaraan negara di semua bidang termasuk bidang politik.

\footnotetext{
${ }^{18}$ T.B. Simatupang, "Partisipasi Kristen dalam Revolusi di Bidang Politik" dalam Partisipasi Kristen dalam Nation Building di Indonesia, h. 22,23

${ }^{19}$ Zacharia J. Ngelow, "Beberapa Catatan Mengenai Politik Kristen di Indonesia" dalam Teologi Politik, Panggilan Gereja di Bidang Politik Pasca Orde Baru (Makassar: Yayasan OASE INTIN, 2013), h. 21

${ }^{20}$ T.B. Simatupang, "Partisipasi Kristen dalam Revolusi di Bidang Politik" dalam Partisipasi Kristen dalam Nation Building di Indonesia, h. 23.
} 
Demi mencapai tujuan itu maka didirikanlah satu organisasi politik yang diberi nama: "Partai Kristen Nasional" (PKN) yang dipimpin oleh Dr. W.Z. Johanes ${ }^{21}$. Dalam Kongres yang pertama dari PKN di Solo pada tanggal 28 November 1945, nama PKN diganti dengan nama: "Partai Kristen Indonesia (PARKINDO). Partai ini merupakan satu-satunya organisasi politik bagi seluruh umat Kristen di Indonesia. Namun oleh karena kesulitan komunikasi dengan daerah-daerah maka di Sumatera Utara didirikanlah PARKI (Partai Kristen Indonesia). Sesudah sidang KNIP di Malang pada bulan Maret 1947, di mana hadir juga pengurus PARKI maka dibahas mengenai penyatuan PARKI dengan PARKINDO. Maka dalam Kongres PARKI pada tanggal 19-20 April 1947 bertempat di Prapat diputuskan bahwa PARKI melebur ke dalam PARKINDO. Dengan demikian, orang Kristen Protestan memiliki hanya satu partai politik yang menyalurkan aspirasi politiknya di Indonesia yaitu: PARKINDO. Melalui partai politik ini, orang Kristen di Indonesia menyatakan kepada orang Kristen di Belanda bahwa orang Kristen di Indonesia telah turut memproklamirkan kemerdekaan Indonesia dan akan terus mempertahankannya ${ }^{22}$. Sambutan orang Kristen di Indonesia terhadap hadirnya partai politik ini cukup besar sehingga sejak kemerdekaan RI, orang Kristen sebagai anggota dari PARKINDO selalu mendapat posisi dalam Kabinet.

Walaupun PARKINDO telah menjadi saluran aspirasi politik bagi umat Kristen Protestan di Indonesia, namun ada sebagian orang Kristen yang menyalurkan aspirasi politiknya melalui partai politik yang lain, antara lain: PNI (Partai Nasional Indonesia), MURBA dan PSI (Partai Sosialis Indonesia). Bahkan ada yang menduduki posisi penting sebagai menteri ${ }^{23}$.

Ketika Dewan Gereja-gereja di Indonesia (DGI) didirikan pada bulan Mei 1950 dan setelah gereja-gereja di Indonesia mengambil bagian dalam Dewan Gereja-gereja se-Dunia (DGD) maka gereja mulai mengembangkan pemikiran-pemikiran teologis-politis yang lebih luas. Pada pembukaan DGI, satu-satunya ceramah yang disampaikan adalah dari dr. J. Leimena. Dalam sesi diskusi, salah satu masalah yang diangkat adalah tugas tugas negara terhadap orang Kristen. Merespons persoalan itu, Leimena menekankan perlunya adanya penyelenggaraan negara secara bertanggung jawab, berpegang pada hukum dan aturan sehingga masyarakat dapat hidup dengan sempurna. Lebih jauh Leimena juga menegaskan bahwa tugas negara uga ada batasnya. Negara juga tidak bisa berlaku mutlak. Negara juga harus memberikan pertanggungjawaban atas penyelenggaraan politis kepada Tuhan dan kepada rakyat secara menyeluruh. Alassan Leimena adalah bahwa dalam perjuangan kemerdekaan, semua pihak ikut terlibat termasuk orang-orang Kristen dan orang-orang dari etnik Cina. Leimena juga mengingatkan mengenai pengaruh Komunisme. Oleh sebab itu ia menganjurkan gereja agar menempuh kebijakan prefentif dari pada kuratif dengan membendung pengaruh dari Komunisme. Topik ini mendorong DGI yang baru dibentuk itu sehingga memberikan perhatian yang serius terhadap bidang politik ${ }^{24}$

Dalam upaya mencegah pengaruh-pengaruh negatif dalam gereja maka gereja-gereja diingatkan untuk mengembangkan pemikiran teologis politis yang lebih kritis terhadap fenomena-fenomena yang berkembang dalam masyarakat. Bagi maksud itu telah dirumuskan beberapa point sebagai dasar teologis Alkitabiah yang menjadi pedoman bagi orang Kristen

\footnotetext{
${ }^{21}$ T.B. Simatupang, "Partisipasi Kristen dalam Revolusi di Bidang Politik" dalam Partisipasi Kristen dalam Nation Building di Indonesia, h. 23.

${ }^{22}$ T.B. Simatupang, "Partisipasi Kristen dalam Revolusi di Bidang Politik" dalam Partisipasi Kristen dalam Nation Building di Indonesia, h. 25.

${ }^{23}$ T.B. Simatupang, "Partisipasi Kristen dalam Revolusi di Bidang Politik" dalam Partisipasi Kristen dalam Nation Building di Indonesia, h. 26

${ }^{24}$ DGI, Notulen: Rencana Acara Pembentukan Dewan Gereja-gereja di Indonesia, 21-28 Mei 1950 di Jakarta; lihat juga Ayub Ranoh, "Kristen dan Politik di Indonesia, Refleksi Historis" dalam Teologi Politik: Agama-agama Kekuasaan, Jakarta:Badan Penelitian dan Pengembangan PGI, 2004)
} 
dalam menjalankan tanggung jawab politiknya. Rumusan-rumusan itu antara lain sebagai berikut:

a. "Orang-orang Kristen harus memenuhi tanggung jawabnya terhadap nasib bangsa dan negara melalui partisipasi yang penuh rasa tanggung jawab dalam bidang politik....harus dijalankan dalam terang injil mengenai kerajaan Allah secara positif, kreatif, kritis dan realistis.

b. Gereja tidak dapat mengidentikan dirinya dengan suatu sistem politik, dan juga suatu partai politik bahkan partai politik Kristen sekalipun.

c. Gereja berkewajiban mempersiapkan anggota-anggotanya agar mereka dapat berpartisipasi dengan sabar dan penuh rasa tanggung jawab dalam bidang politik serta gereja harus memberikan pelayanan khusus kepada anggota-anggotanya yang mempunyai tanggung jawab yang berat dalam bidang politik.

d. Diberikan arti yang kreatif bagi PARKINDO dalam rangka melaksanakan tugas Kristen di bidang politik berdasarkan kenyataan-kenyataan politik di Indonesia. PARKINDO juga diingatkan akan adanya bahaya-bahaya yang dihadapi oleh suatu partai Kristen.

e. Orang-orang Kristen yang berada di partai politik yang lain juga diingatkan untuk menjalankan tugas Kristen dalam partai politik dan kepada mereka diingatkan agar agar mereka terus menerus bertanya apakah dasar-dasar dari partai itu memberikan ruang bagi mereka untuk menjalankan tugas politiknya sebagai orang Kristen.

f. Kepada orang-orang Kristen yang menjalankan tugas politik dalam partai-partai yang berlainan dianjurkan agar mengadakan kerjasama"25.

\section{Peranan orang Kristen di Bidang Politik pada Era Orde Lama hingga Orde Reformasi.}

\section{A. Orde Lama}

Era Orde lama ditandai dengan pemerintahan Presiden Soekarno sejak tahun 19451965. Dalam era pemerintahan ini, orang-orang Kristen terus berperan dalam pusaran politik di Indonesia melalui PARKINDO maupun melalui organisai politik yang bersifat nasionalis maupun sosialis untuk bersama dengan partai politik yang lainnya meletakan dasar-dasar berpijak yang kuat sebagai fondasi dalam penyelenggaraan pemerintahan. Bagi maksud itu. umat Kristen berusaha mempertahankan hubungan baik dengan presiden sebagai kepala negara dengan mengundangnya untuk menghadiri acara-acara yang bersifat nasional untuk menjamin kebebasan beragama dan memelihara Pancasila.

Hubungan yang baik itu dijadikan sebagai sarana dimana orang-orang Kristen diajak untuk memberikan dukungan politik kepada Presiden, yang mengumumkan revolusi dan meluncurkan Demokrasi Terpimpin serta Manifesto Politik ${ }^{26}$. Dalam bukunya, yang berudul: "Tanggung Jawab Gereja dan Orang Kristen di bidang Politik", Notohamidjojo mengungkapkan bahwa pada tahun 1960, Konferensi para Pendeta (Kopenda) di Solo telah dijadikan sebagai sarana pesemaian indoktrinasi Manipol Usdek oleh Departeman Penerangan dan Lembaga Pembina Jiwa Revolusi. Para pendeta dianjurkan untuk menyebar-luaskan ajaran Manipol Usdek dari mimbar-mimbar gereja. Apalagi dalam Sidang Dewan Gereja-gereja di Indonesia, ditegaskan oleh Pemimpin Besar Revolusi bahwa tujuan revolusi Indonesia paralel dengan tujuan agama Kristen. Lalu banyak orang Kristen percaya bahwa keparalelan tujuan itu benar.

\footnotetext{
${ }^{25}$ T.B. Simatupang, "Partisipasi Kristen dalam Revolusi di Bidang Politik" dalam Partisipasi Kristen dalam Nation Building di Indonesia, h. 27

${ }^{26}$ Manipol/USDEK merupakan akronim dari Manifesto Politik, Undang-undang Dasar 1945, Sosialisme Indonesia, Demokrasi Terpimpin, Ekonomi Terpimpin, dan Kepribadian Indonesia.
} 
Karena anjuran pada waktu itu demikian kuat sehingga para pendeta merasa kurang lengkap bila tidak menyinggung ajaran Manipol Usdek itu dalam khotbah-khotbahnya. Bahkan ada Majelis Jemaat yang menginginkan agar kemajelisan dalam gereja harus disusun sedemikian rupa sehingga ada anggota majelis yang berasal dari: Partai Nasionalis Indonesia (PNI), PARKINDO, dan PKI. Notohamidjojo menilai bahwa sikap para pendeta dan Majelis Jemaat ini membuktikan bahwa kebanyakan orang Kristen, khususnya para pemimpin gereja (pendeta) belum siap menghadapi infiltrasi politik ke dalam gereja. Ternyata dikemudian hari Demokrasi Terpimpin itu mengarah kepada pemusatan kekuasaan di tangan satu orang dan totalitarisme tidak bisa terhindarkan ${ }^{27}$.

Munculnya demokrasi terpimpin ini adalah sebagai akibat dari gagalnya demokrasi liberal atau demokrasi parlementer yang diberlakukan sejak tahun 1945-1959 dan memungkinkan adanya multi partai. Gagalnya demokrasi liberal atau parlementer ini disebabkan oleh kenyataan bahwa bangsa Indonesia belum berpengalaman atau belum matang dalam berdemokrasi ${ }^{28}$. Akibatnya demokrasi terpimpin diberlakukan oleh Presiden Soekarno. Dalam pemberlakukan demokrasi terpimpin itu Kepala Negara membubarkan DPR dan MPR yang merupakan hasil pemilihan rakyat. Lalu Kepala Negara mengangkat Ketua DPR, MPR, DPA, Mahkamah Agung, Kejaksaan Agung, dan Panglima ABRI. ${ }^{29}$ Kalau dalam demokrasi liberal atau demokrasi perlementer terjadi pertarungan antar Partai dalam berbagai idiologi maka dalam demokrasi terpimpin kekuasaan terpusat pada satu tangan yaitu di tangan Presiden sebagai pemimpin utama. Namun segera terjadi pula pertarungan antara Kepala Negara dengan ABRI yang juga ingin berperan dalam bidang politik ${ }^{30}$.

Pertanyaan yang timbul adalah bagaimana seharusnya tugas gereja atau orang-orang Kristen dalam situasi politik yang demikian? Menjawab pertanyaan ini, Notohamidjojo mengemukakan empat tugas. Pertama, gereja dan orang Kristen harus mencegah pendewaan terhadap negara. Maksudnya adalah idiologi negara jangan sampai menjadi idiologi yang bersifat religius atau idiologi agama. Pelaksanaan tugas ini bisa menimbulkan dua tindakan dari negara, yakni ditindas atau sebaliknya gereja bisa dijadikan sebagai pewarta idiologi negara yang bersifat agama itu. Kedua, gereja mesti berusaha sungguh-sungguh menjadi eklesia untuk mengingatkan kepada semua pihak termasuk negara yang memiliki kuasa pedang bahwa negara dapat mengatasi kejahatan dengan kebaikan. Ketiga, kehadiran orang Kristen dalam bidang politik adalah melayani semua orang dalam masyarakat berdasarkan keadilan, kebenaran, kejujuran dan kesetiaan. Keempat, gereja dapat menyediakan tempat pertemuan diantara golongan-golongan politik yang meraneka ragam mengenai kebijaksanaan pemerintahan negara. Sebab di Indonesia misalnya, tidak semua orang Kristen menjadi anggota partai Kristen. Ada juga orang Kristen yang masuk partai yang bersifat nasionalis dan sosialis. Maka gereja dapat melakukan pertemuan bersama dengan semua golongan politik yang berbeda itu ${ }^{31}$.

Lebih tegas lagi peserta Konferensi Nasional gereja-gereja yang berlangsung di Salatiga menegaskan bahwa gereja memang tidak mengambil bagian dalam pemerintahan negara atau dalam politik praktis, sebab gereja tidak identik dengan suatu partai politik, tetapi gereja dapat menggugah hati nurani masyarakat dan pemerintah dengan menyatakan kehendak Tuhan. Dalam situasi di mana organisasi politik sebagai sarana menyalurkan hati nurani rakyat tidak didengarkan maka gereja bersama dengan golongan agama lain dapat mengingatkan pemerintah bahwa kekuasaan harus selalu berpedoman kepada keadilan dan kebenaran. Lebih

\footnotetext{
${ }^{27}$ O. Notohamidjojo, Tanggung Jawab Gereja dan Orang Kristen di Bidang Politik (Jakarta: BPK, 1967) h. 8

${ }^{28}$ Ayub Ranoh, "Demokrasi Politik dan Demokrasi Ekonomi, Perspektif Kristen" dalam Teologi Politik, Penggilan Gereja di bidang Politik Pasca Orde Baru (Makassar: Yayasan Oase Intim, 2013) h. 82

${ }^{29}$ O. Notohamidjojo, Tanggung Jawab Gereja dan Orang Kristen di Bidang Politik, h. 9

${ }^{30}$ Ayub Ranoh, "Demokrasi Politik dan Demokrasi Ekonomi, Perspektif Kristen", h. 82

${ }^{31}$ O. Notohamidjojo, Tanggung Jawab Gereja dan Orang Kristen di Bidang Politik, h. 63,64.
} 
jauh Konferensi itu menegaskan bahwa tugas gereja adalah secara terus menerus mempersiapkan anggota-anggotanya untuk turut serta sebagai orang-orang Kristen yang bertanggung jawab dalam bidang politik. ${ }^{32}$

\section{B. Orde Baru}

Pada awal era Orde Baru (1966-1998), dilakukan koreksi terhadap demokrasi terpimpin dan diberlakukanlah demokrasi Pancasila. Namun pada parohan kedua era Orde Baru, penguasa sangat menekankan kontrol idiologis terhadap berbagai bidang kehidupan sehingga cenderung mengarah kepada sisten yang bersifat otoriter. Pada era ini jumlah partai politik diperkecil dan sebagai akibatnya, PARKINDO sebagai organisasi politik orang Kristen yang menyalurkan aspirasi politiknya dilebur ke dalam Partai Demokrasi Indonesia pada tahun $1972^{33}$, sehingga orang-orang Kristen tidak lagi menyampaikan aspirasi politik dan berjuang melalui partai politik Kristen melainkan melalui partai-partai politik yang bersifat nasionalis. Memang, masih ada lembaga-lembaga demokrasi dan organisasi-organisasi politik seperti partai-partai, yakni partai Golkar sebagai partai pemerintah, di mana baik birokrat sipil maupun militer menjadi anggotanya, Partai Persatuan Pembangunan (PPP) dan Partai Demokrasi Indonesia (PDI), tetapi Golkar sebagai partai penguasa sangat besar pengaruhnya.

Pada era ini, pemilihan umum juga masih tetap dilakukan setiap lima tahun di mana rakyat diberikan kesempatan untuk memilih pemimpinnya, namun pemilihan itu dilakukan sebagai formalitas saja, sebab pasti yang menang adalah partai Golkar sebagai pertai pemerintah. Dengan demikian, masih ada Lembaga Legislatif tetapi karena interfensi yang begitu kuat dari Golkar dan militer maka hukum lebih berpihak pada penguasa dari pada rakyat. Sebab faktor yang sangat dominan pada era ini adalah kekuatan militer dengan dwifungsi ABRI dan kontrol idiologis yang begitu kuat dari partai penguasa. Pemusatan kekuasaan ditangan penguasa ini membuat rakyat menjadi muak tetapi mereka tidak berdaya untuk melakukan perubahan. Situasi ini mencapai puncaknya ketika kalangan intelektual dan para mahasiswa melakukan protes dan demonstrasi secara masal sehingga berhasil mengundurkan tokoh utama dari rezim ini ${ }^{34}$.

Dalam periode ini, perlu dicatat beberapa peristiwa yang bersifat religius-politis yang berkaitan dengan hubungan kelompok Islam dan Kristen. Pada tanggal 1 Oktober 1967, terjadi penghancuran gereja-gereja, dan sekolah-sekolah Kristen oleh kelompok organisasi Islam di Makassar. Karena ketegangan meningkat maka diadakanlah musyawarah antar umat beragama di Jakarta pada tanggal 30 November 1967. Dalam musyawarah tersebut, Presiden Soeharto meminta agar penyebaran agama tidak boleh mengarah pada konflik. Agama-agama harus berjalan dalam hubungan yang harmonis dan mempromosikan semangat saling menghormati dan toleransi. Pada pertemuan tersebut, para peserta menyusun deklarasi bersama untuk menciptakan kehidupan yang harmonis di antara agama-agama. Tetapi orang-orang Kristen menolak klausa yang berbunyi: "Seseorang tidak boleh menyebarkan kepercayaannya kepada orang lain yang telah memiliki agama." Karena itu berarti bahwa misi Kristen atau Islam hanya boleh diarahkan untuk memperdalam iman umatnya masing-masing ${ }^{35}$.

Beberapa tahun kemudian, ketika dilihat bahwa pembangunan gedung gereja semakin meningkat maka berbagai tindakan diambil oleh pemerintah untuk membatasi ruang gerak

\footnotetext{
32 S.A.E. Nababan, Panggilan Kristen dalam Pembaruan Masyarakat, Laporan Konperensi Nasional Gereja dan Masyarakat (Jakarta: BPK, 1968) h. 25,26.

33 Zacharia J. Ngelow, "Pedoman Pelayanan Gereja di Bidang Politik" dalam Teologi Politik, Penggilan Gereja di bidang Politik Pasca Orde Baru, h. 294

${ }^{34}$ Ayub Ranoh, "Demokrasi Politik dan Demokrasi Ekonomi, Perspektif Kristen", h. 83

35 Jan S. Aritonang, Sejarah Perjumpaan Kristen dan Islam di Indonesia, (Jakarta: BPK Gunung Mulia, 2004) h.391
} 
orang Kristen melalui Surat Keputusan Bersama Menteri Agama dan Menteri Dalam Negeri (disingkat: SKB No. 1 tahun 1969), bahwa pembangunan gedung gereja harus disetujui oleh mayoritas penduduk setempat. Tentu saja, orang-orang Kristen menolaknya. Pada tahun 1978, Menteri Agama mengeluarkan Keputusan No. 70 dan 77, yang melarang penyebaran agama ditujukan kepada orang-orang yang telah memeluk agama lain, dengan bujukan dan pamflet. Keputusan itu juga melarang mengunjungi rumah-rumah orang-orang yang memiliki agama lain ${ }^{36}$. Ketegangan dan konflik yang bernuansa politik dan agama terus meningkat, terutama pada akhir Orde Baru dan menjelang awal Orde Reformasi. Konflik itu mencapai puncaknya pada kerusuhan di Jakarta ${ }^{37}$ dan kemudian menyebar ke banyak kota di Indonesia yang menyebabkan banyak korban jiwa dan kerugian material. Kemudian kerusuhan menyebar ke Kupang, Ambon, dan Poso dan daerah-daerah lain sehingga memakan lebih banyak korban jiwa.

\section{Orde Reformasi}

Di tengah-tengah situasi konflik itu, telah terjadi pergantian pemimpin negara, mulai dari B.J. Habibi (21 Mei 1998-20 Oktober 1999), Gus Dur (20 Oktober 199-23 Juli 2001), Megawati (23 Juli 2001-20 Oktober 2004), Sosilo Bambang Yudoyono (20 Oktober 2004-20 Oktober 2014), dan sekarang Joko Widodo (20 Oktober 2014- hingga sekarang). Konflik antar etnis yang bernuansa agama itu terus berlanjut muncul keinginan untuk menghentikan konflik berdarah dan memulai kehidupan yang harmonis dan damai. Pemerintah Pusat memprakarsai upaya perdamaian pada 19-20 Desember 2001 di Malino. Pertemuan tersebut menghasilkan Deklarasi Malino I. Isinya adalah: untuk menghentikan semua bentuk konflik, mematuhi upaya penegakan hukum, meminta pihak berwenang untuk bertindak tegas dan adil, menjaga terciptanya suasana damai, menghilangkan semua bentuk fitnah dan menciptakan kehidupan yang harmonis. Dikatakan juga bahwa setiap warga negara memiliki hak untuk hidup dalam damai; semua properti harus dikembalikan ke pemiliknya yang sah; pengungsi dapat kembali ke kampung halaman mereka masing-masing; Infrastruktur akan di rahabilitasi, dan menjalankan hukum agama masing-masing dengan hormat. Namun, karena konflik masih berlangsung di Ambon (1999-2002) dan Poso, pemerintah memulai perjanjian damai Malino II pada 12 Februari 2002, yang isinya hampir sama dengan perjanjian damai Malino I. ${ }^{38}$

Setelah kesepakatan Malino I dan II, suasana konflik antar umat beragama di Indonesia mulai agak mereda. Namun mulai muncul gejala-gejala adanya konflik antara para legislatif dan eksekutif serta antar tokoh politik dalam bidang politik. Situasi ini, jika tidak dikelola dengan baik, maka akan bisa memunculkan kekuatan dari agama tertentu yang menginginkan berdirinya negara teokrasi di Indonesia. Penggalangan masa yang bersifat agama dan ujaranujaran yang memecah belah kehidupan bersama antara berbagai golongan dalam masyarakat perlu diwaspadai.

Ketika pemerintahan Orde baru runtuh maka Indonesia memasuki suatu kehidupan demokrasi yang baru. Di satu pihak masih memakai demokrasi Pancasila tetapi dengan model atau kharakter yang baru. Di pihak lain, dalam demokrasi pada era Reformasi ini dimungkinkan adanya multi partai sehingga mirip dengan demokrasi parlementer pada era Presiden Soekarno. Pada masa pemerintahan Habibi, diberikan peluang bagi masyarakat Indonesia untuk membentuk partai politik, sehingga muncul partai-partai baru yang meramaikan panggung politik di Indonesia. Di kalangan orang Kristen muncul satu partai Kristen yang diberi nama Partai Damai Sejahtera (PDS) yang didirikan pada I Oktober 2001. Pada pemilu 2004, partai Kristen ini mendapat sambutan yang cukup besar sehingga mendapatkan 13 kursi di parlemen.

\footnotetext{
${ }^{36}$ Jan S. Aritonang, Sejarah Perjumpaan Kristen dan Islam di Indonesia, h.430,431

${ }^{37}$ https://en.wikipedia.org/wiki/May_1998_riots_of_Indonesia

${ }^{38} \mathrm{http}: / /$ labholonk.blogspot.co.id/2008/05/perjanjian-damai-maluku-di-malino.html diunduh pada $27 \mathrm{Mei}$ 2016
} 
Tetapi pada pemilu 2009, suara pendukung partai ini berkurang drastis sehingga perolehan suara kurang dari 2.5 persen untuk memenuhi syarat ambang batas pemilu (electoral threshold). Akibatnya partai ini kehilangan semua kursi di parlemen ${ }^{39}$. Namun demikian, aspirasi politik orang Kristen di Indonesia masih terus disampaikan melalui partai-partai nasionalis di Indonesia.

\section{Kesimpulan}

Pertama. Peranan orang Kristen dalam pusaran politik di Indonesia telah berlangsung sejak berada-abad lalu, mulai dari zaman penjajahan Belanda. Perjuangan itu dimulai dengan pembentukan organisasi-organisasi kedaerahan yang terutama bergerak di bidang moral, kerohanian dan peningkatan taraf hidup serta pendidikan, karena dalam iklim penjajahan, organisasi yang bersifat politis tentu dicurigai oleh penguasa. Namun, organisasi-organisasi sosial dan kerohanian itu secara diam-diam mempersiapkan masyarakat Indonesia agar di suatu waktu di masa depan, bisa mendirikan satu bangsa yang merdeka.

Kedua, pada awal abad ke dua puluh, mulai muncul semangat nasionalisme dengan gerakan "Budi Utomo" pada tahun 1908, diikuti dengan "Sumpah pemuda" pada tahun 1928. Gerakangerakan nasionalisme itu mendorong masyarakat, khususnya di lingkungan pemuda untuk membentuk organisasi-organisasi yang bersifat politik pada level daerah, dengan sebutan Jong Ambon, Jong Minahasa, Jong Selebes, Jong Jawa, Jong Sumatera, dsbnya.

Ketiga, kelompok-kelompok organisasi kepemudaan ini kemudian disatukan dalam organisasi-organisasi yang bersifat nasional. Dengan begitu mulai terhimpun kekuatankekuatan rakyat yang lebih besar yang dipelopori oleh tokoh-tokoh baik Kristen maupun non Kristen untuk mendukung gerakan nasionalisme yang semakin menguat dalam masyarakat. Beberapa organisasi yang bisa disebutkan adalah Gerindo, GAPI PNI dsbnya. Gerakan nasionalisme itu mencapai puncaknya ketika diproklamasikan kemerdekaan Indonesia pada tanggal 17 Agustus 1945. Salah stu perjuangan kelompok Kristen dalam peralanan sejarah bangsa ini adalah, berjuang untuk menghapus piagam Jakarta dari UUD'45 dan kalimat "Presiden haruslah orang Islam".

Keempat, sesudah Indonesia merdeka maka kekuasaan tidak lagi berada di tangan penjajah, melainkan sudah berada di tangan rakyat Indonesia. Namun untuk mempertahankan kemerdekaan Indonesia dan demokrasi yang baru itu, seluruh rakyat Indonesia harus bahu membahu mengusir penjajah untuk merebut kembali daerah-daerah yang masih dikuasai. Perang untuk mempertahankan kemerdekaan itu dilakukan oleh seluruh rakyat dan semua golongan termasuk orang-orang Kristen dengan air mata dan pertumpahan darah. Akhirnya Indonesia sebagai negara yang bermartbat diakui oleh dunia.

Kelima, Setelah Indonesia memperoleh kedaulatan penuh, maka diberlakukanlah berbagai eksperimen demokrasi di Indonesia, mulai dari demokrasi parlementer, demokrasi terpimpin pada era Soekarno, lalu beralih ke demokrasi Pancasila pada era Soeharto, rakyat Indonesia mengalami pasang surutnya perebutan kekuasaan. Dalam situasi ini, orang-orang Kristen tidak hanya berjuang untuk menyalurkan aspirasi politiknya melalui partai-partai yang berlabelkan nama Kristen melainkan juga melalui partai-partai nasionalis yang ada. Pada masa reformasi, orang-orang Kristen terus berperan dalam bidang politik, sebagai salah satu bidang di mana

${ }^{39}$ Dikutip dari: https://id.m.wikipwdia.org pada tanggal 24 September 2018. 
diutus untuk berjuang bersama dengan partai-partai dan golongan-golongan lain di Indonesia untuk mewujudkan Indonesia yang adil, sejahtera dan damai.

\section{Daftar Pustaka}

Aritonang, Jan S., Sejarah Perjumpaan Kristen dan Islam di Indonesia (Jakarta: BPK Gunung Mulia, 2004)

DGI, Notulen: Rencana Acara Pembentukan Dewan Gereja-gereja di Indonesia, 21-28 Mei 1950 di Jakarta

de Jonge, Ch., "Gereja Masehi Injili Minahasa 1934-1942, Berdiri sendiri Di Bawah Perwalian" dalam Apostole, Pengutusan (Jakarta: STT Jakarta, 1987)

Nababan, S.A.E. Panggilan Kristen dalam Pembaruan Masyarakat, Laporan Konperensi Nasional Gereja dan Masyarakat (Jakarta: BPK, 1968) 
Ngelow, Zakaria J., Kekristenan dan Nasionalisme, Perjumpaan Umat Kristen Protestan dengan pergerakan Nasional Indonesia 1900-1950 (Jakarta: BPK Gunung Mulia, 1996)

Ngelow, Zakaria J., "Beberapa Catatan Mengenai Politik Kristen di Indonesia" dalam Teologi Politik, Panggilan Gereja di Bidang Politik Pasca Orde Baru (Makassar: Yayasan OASE INTIN, 2013)

Ngelow, Zakaria J., "Pedoman Pelayanan Gereja di Bidang Politik" dalam Teologi Politik, Panggilan Gereja di bidang Politik Pasca Orde Baru (Makassar: Yayasan OASE INTIM, 2013)

Notohamidjojo, O., Tanggung Jawab Gereja dan Orang Kristen di Bidang Politik (Jakarta: BPK, 1967)

Ranoh, Ayub, "Demokrasi Politik dan Demokrasi Ekonomi, Perspektif Kristen" dalam Teologi Politik, Penggilan Gereja di bidang Politik Pasca Orde Baru (Makassar: Yayasan OASE INTIM, 2013)

Ranoh, Ayub, "Kristen dan Politik di Indonesia, Refleksi Historis" dalam Teologi Politik: Agama-agama Kekuasaan, Jakarta:Badan Penelitian dan Pengembangan PGI, 2004)

Sibarani, Poltak J.B., Bolehkah Gereja Berpolitik. Mencari Pola Hubungan Gereja dan Negara yang relevan di Indonesia (Jalarta: Ramos Gospel Bubl. House, 2004)

Sidjabat, W.B., "Partisipasi Pemuda Kristen dalam Nation Building di Indonesi dalam abad ke XX" dalam Partisipasi Kristen dalam Nation Building di Indonesia, disusun oleh W.B. Sidjabat (Jakarta: BPK., 1968)

Simatupang, T.B., "Partisipasi Kristen dalam Revolusi di Bidang Politik" dalam Partisipasi Kristen dalam Nation Building di Indonesia, disusun oleh W.B. Sidjabat (Jakarta: BPK., 1968)

\section{Sumber Internet:}

https://en.wikipedia.org/wiki/May_1998_riots_of_Indonesia diunduh 20 September 2018 http://labholonk.blogspot.co.id/2008/05/perjanjian-damai-maluku-di-malino.html diunduh pada 20 September 2018

https://id.m.wikipwdia.org pada tanggal 24 September 2018 